\title{
EFFECTIVENESS FACTORS IN INTERIM MANAGEMENT PROJECTS - RESEARCH CONCEPT
}

\author{
Beata SKOWRON-MIELNIK ${ }^{1 *}$, Grzegorz SOBIECKI ${ }^{2}$ \\ ${ }^{1}$ Poznań University of Economics and Business, Poznań; beata.mielnik@ue.poznan.pl, \\ ORCID: 0000-0001-9285-0413 \\ ${ }^{2}$ BMPS Consulting, Milanówek; gsobiecki@bmps.pl, ORCID: 0000-0002-7875-6153 \\ * Correspondence author
}

Purpose: The aim of studies undertaken in the article is to identify factors that may have an effect on the relationship between the results of interim management projects and increasing their effectiveness.

Design/methodology/approach: An empirical-inductive approach - the literature studies and secondary empirical data analyses.

Findings: The authors point to the following three key factors: trust, power and knowledge. In the future, the results of the studies presented here will form the foundations to develop an empirical-inductive research program with the aim to verify the significance of the identified factor, the relationships between them and their effect on the effectiveness of the process. It applies not only to commercial organizations, but also to non-profit institutions, political organizations and public utility organizations, such as health care institutions.

Practical implications: This article refers to the effectiveness of the implementation process of interim management projects. The effectiveness of the whole process is strongly conditioned by both the competence of the interim manager and the perception of the client. Research results can be used to improve these competences and to improve the effectiveness of IM projects.

Originality/value: The pioneering nature of work aimed at filling the existing research gap and answering the research question made the authors opt for an empirical-inductive approach.

Keywords: interim management, effectiveness factors, power, trust, knowledge.

Category of the paper: Conceptual paper.

\section{Introduction}

Interim management (hereinafter also IM) is worldwide understood as an approach to the transformation of companies but also non-profit institutions and even political and public utility organizations, such as public healthcare (Eurofound, 2015; Eurofound, 2018). In Poland, an interim manager is a relatively young profession. Unlike in other countries, projects 
involving the presence of interim managers (hereinafter also IM or IMs) are here implemented most probably only in commercial entities - at least to our knowledge (Wendt, 2019; Rytka, 2019; Sobiecki, 2019). Neither is there much research available on interim management in Poland that would distinguish it from other approaches to the transformation of organization, while pointing to elements specific to IM projects and increasing their chance to succeed.

There is therefore a research gap which consists of two perspectives: that of the impact of using IM project tools (operational) and that of the cultural impact (organizational). Only a few publications exist in Poland, for example Mądra et al. (2014), that refer to these perspectives in a comprehensive way, offering a discussion in which a more detailed approach to a variety of IM components is proposed in terms of their effectiveness. While these proposals cannot be rejected, it must be emphasized that they are essentially declarative in nature. They are only partly based on literature and mostly on descriptive empirical conclusions of a team of interim managers, e.g. authors of the aforementioned publication (Mądra et al., 2014), who collected their observations throughout several years of their experience with IM projects.

To fill this gap, research questions have been suggested following the approach developed by Punch in his research model (2016, p. 47). Using this model, our own research program is attempted in which the organizational perspective is adopted to formulate hypotheses regarding IM projects in terms of a relationship between the IM project impact and selected factors behind it.

Punch (2016) divides his research program and its hypotheses into two stages: pre-empirical and empirical, as illustrated in Figure 1.

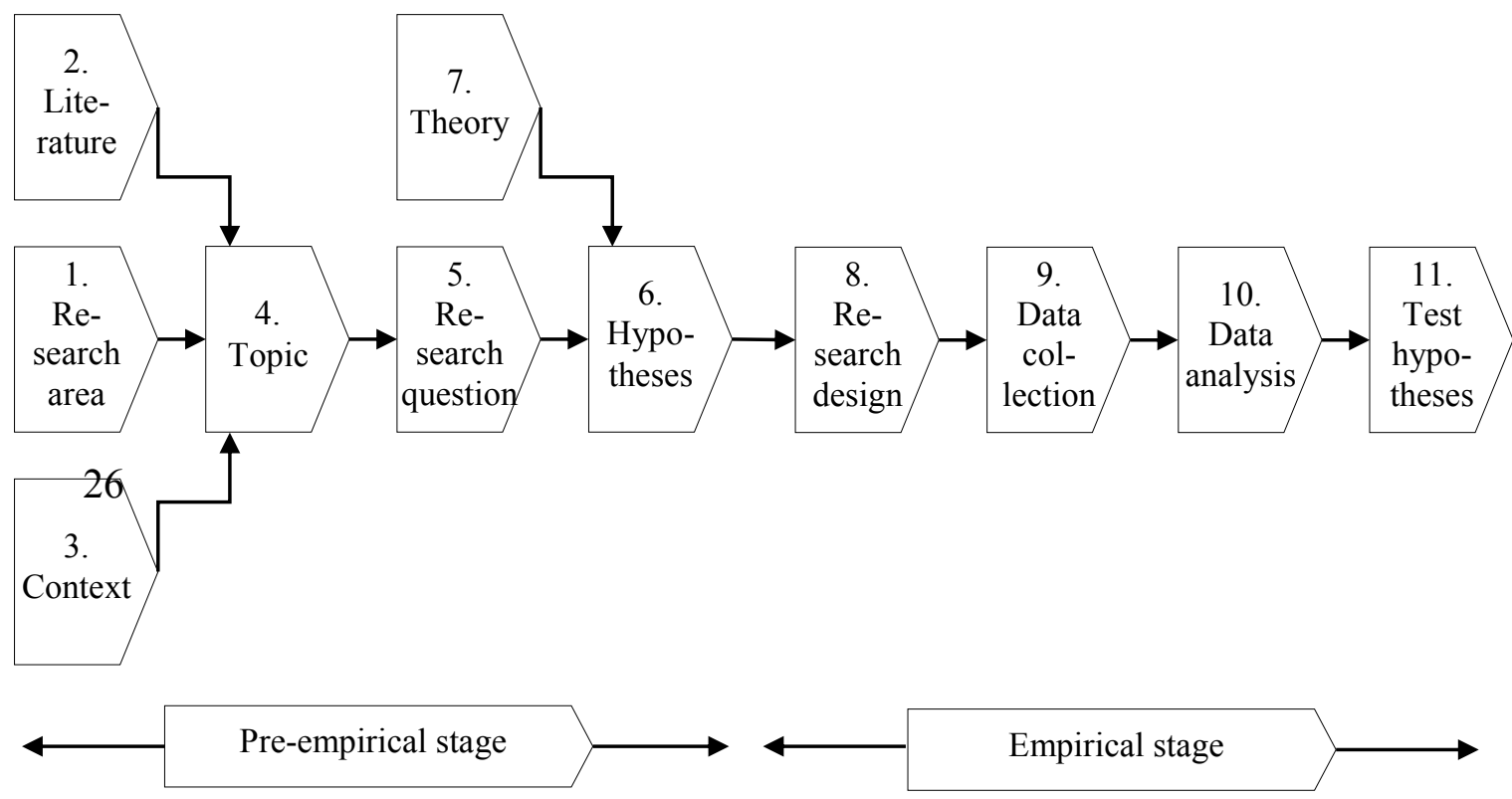

Figure 1. Model of the research program. Adapted from: "Developing Effective Research Proposals" by K.F. Punch, 2016, London, California, New Delhi, Singapore: Sage Publications. 
With interim management literature still scarce and practice in Poland relatively young, the challenge undertaken in this article seems clear. Being aware of this, the authors of this article chose to rely on the model in Figure 1 and its cyclical approach to building a research process. The consequences of this approach for the research practice may be described by paraphrasing what Punch says about his model (2016, p. 46):

"While this description has organization and structure, this does not mean that developing a proposal does (or should) proceed in the tidy, organized, deductive way. It is possible for the proposal to be developed this way. But it's more likely that its development will be a messy, cyclical process, with hesitations and frustrations, where the researcher cycles backwards and forwards between different issues and different sections, iterating towards a final version".

This methodological approach refers to a well-established theory, i.e. building a theory based on systematically collected empirical data. Such theory derives therefore from an analysis of empirical data and eventually emerges in the course of systematically conducted field studies, from empirical data that directly relates to the observed part of social reality (Glaser and Strauss, 2009). Hypotheses, concepts and their properties are constructed, modified and verified in the course of empirical research. Thus, developing a theory is closely related to a long-term research process. Several iterations were made which led to preliminary conclusions. While at this stage they are documented well enough to be published, this article focuses on presenting not so much the research program in its final form but rather the research concept behind it (discussed in detail in Section 4). The research program is proposed to be developed based on an empirical-inductive concept which takes into account a combination of three pre-selected factors of IM project effectiveness: Trust, Power and Knowledge.

\section{Interim management from the perspective of the organization's needs}

A research program based on such factors as Trust, Power and Knowledge requires to be implemented repeatedly as IM projects in real business organizations if it is to confirm the extent to which the applied IM solutions may contribute to project effectiveness, i.e. meet the needs of a given organization. The thesis assuming the application of IM solutions to meet these needs implies a mechanism of repetitive and effective implementation of such solutions, i.e. the existence of the respective methodology. While literature offers a number of mechanisms, they are typically empirical and not sufficiently proven scientifically. Goss and Bridson (1998, as cited in Sobiecki, 2018, p. 150) studied approximately 80 sources, concluding that:

"Literature on interim management is predominantly found in the practitioner press (...) and often consists of $(. .$.$) consultancy reports and interviews with leading proponents - usually$ partners of consultancies specializing in placing interim managers. Many of these contributions 
are more marketing exercise than serious analysis and offer interim management as a product (...) rather than a complex HR process".

Following this observation, as shown in Table 1 (Machi and McEnvoy, 2016, p. 66, as cited in Sobiecki, 2018 p. 150), for the purposes of this article attempts were taken, albeit failed, to find comprehensive scientific analyses for the respective categories of sources indicated in columns A and B which could be referred to in the discussion on IM and how it meets the organization's needs.

Table 1.

Classification of literature sources

\begin{tabular}{|l|l|l|l|l|}
\hline \multicolumn{1}{|c|}{ Frequency } & \multicolumn{1}{c|}{ A. Years } & \multicolumn{1}{c|}{ B. Months } & \multicolumn{1}{c|}{ C. Weeks } & \multicolumn{1}{c|}{ D. Days } \\
\hline Type of source & $\begin{array}{l}\text { Books, } \\
\text { Monographs and } \\
\text { Dissertations }\end{array}$ & Scientific journals & $\begin{array}{l}\text { Popular science } \\
\text { and industry } \\
\text { magazines }\end{array}$ & Websites, blogs \\
\hline Type of content & $\begin{array}{l}\text { Theoretical } \\
\text { foundations }\end{array}$ & Most recent studies & $\begin{array}{l}\text { Discussions on } \\
\text { current problems }\end{array}$ & $\begin{array}{l}\text { Most recent } \\
\text { discussions and } \\
\text { practices }\end{array}$ \\
\hline
\end{tabular}

Adapted from: "Koncepcja Interim management w praktyce" by G. Sobiecki, 2018, Poznań: Polskie Towarzystwo Nauk o Zdrowiu.

Any search for a precise and unambiguous definition of interim management in literature must end in quoting several different sources, most frequently from column $\mathrm{C}$ or D in Table 1, as it is essentially done by authors of works represented by column B. For example, SkowronMielnik and Bądzio (2016) cite three different definition options (see Table 2).

The respective parts of the definitions in columns $\mathrm{B}$ and $\mathrm{C}$ were organized in a way that matches the order adopted in column A. This allows us to formulate the following three observations:

- There is a relative consistency for every definition to address the same elements in terms of meeting the organization's needs, irrespective of its origin (a Polish source, an international one and a source from one country outside Poland);

- The aforementioned thesis (Machi and McEnvoy, 2016, p. 66 as cited in Sobiecki, 2018 p. 150) is confirmed that industry sources cited in scientific literature tend to describe interim management from the perspective of a product rather than a factor for meeting the organization's needs;

- With the needs of a business organization divided into current/operational and strategic, interim management:

- rather than focusing on the needs which will allow to maintain the standard business model,

- is supposed to lead to model modification or to defend it in crisis situations. 
Table 2.

Definitions of interim management

\begin{tabular}{|c|c|c|c|}
\hline \multirow[b]{3}{*}{ Source } & $\mathbf{A}$ & B & $\mathbf{C}$ \\
\hline & Poland & Worldwide & UK \\
\hline & $\begin{array}{c}\text { Interim Managers } \\
\text { Association of Poland } \\
\text { (SIM, 2014, p. 11) }\end{array}$ & Hays (2016, p. 2) & $\begin{array}{l}\text { Institute of Interim } \\
\text { Management (2016) }\end{array}$ \\
\hline $\begin{array}{l}\text { General } \\
\text { definition }\end{array}$ & $\begin{array}{l}\text { "Interim Management is: } \\
\text { - a temporary operation } \\
\text { within an organization, } \\
\text { with a defined objective } \\
\text { and scope (interim } \\
\text { project), }\end{array}$ & $\begin{array}{l}\text { "An interim manager is } \\
\text { - an external expert } \\
\text { - who provides specific } \\
\text { services } \\
\text { - or consulting services to } \\
\text { the organization } \\
\text { - ad hoc or temporarily; }\end{array}$ & $\begin{array}{l}\text { "Interim management is } \\
\text { - the provision of effective } \\
\text { business solutions" }\end{array}$ \\
\hline $\begin{array}{l}\text { Element of } \\
\text { independence }\end{array}$ & $\begin{array}{l}\text { - implemented by a natural } \\
\text { person (interim manager, } \\
\text { interim), }\end{array}$ & $\begin{array}{l}\text { - an external expert who } \\
\text { works in an organization } \\
\text { but is not employed in it } \\
\text { on a permanent basis, }\end{array}$ & $\begin{array}{l}\text { - "by an independent, } \\
\text { - board or near-board level } \\
\text { manager" }\end{array}$ \\
\hline $\begin{array}{l}\text { Element of } \\
\text { impact }\end{array}$ & $\begin{array}{l}\text { - aimed at achieving } \\
\text { specific, predefined } \\
\text { business results; }\end{array}$ & $\begin{array}{l}\text { - and who facilitates } \\
\text { streamlining of processes } \\
\text { and maximization of } \\
\text { operations" }\end{array}$ & $\begin{array}{l}\text { - "Such complex solutions } \\
\text { - may include } \\
\text { - change } \\
\text { - transformation and } \\
\text { - turnaround management, } \\
\text { - improvement, } \\
\text { - crisis management, } \\
\text { - strategy development." }\end{array}$ \\
\hline $\begin{array}{l}\text { Element of } \\
\text { participation } \\
\text { in risk }\end{array}$ & $\begin{array}{l}\text { - an activity based on } \\
\text { cooperation and } \\
\text { participation in risk and } \\
\text { profit - with respect to the } \\
\text { intended effect." }\end{array}$ & $\begin{array}{l}\text { - active in key moments for } \\
\text { the company }\end{array}$ & - \\
\hline $\begin{array}{l}\text { Element of } \\
\text { qualifications }\end{array}$ & $\begin{array}{l}\text { "An interim manager is } \\
\text { - a high-level specialist } \\
\text { - with a well-documented } \\
\text { experience of succeeding } \\
\text { at the highest levels of } \\
\text { management, }\end{array}$ & $\begin{array}{l}\text { - An interim manager may } \\
\text { also be referred to as a } \\
\text { "manager for special tasks }\end{array}$ & $\begin{array}{l}\text { - delivered by an } \\
\text { independent high-level } \\
\text { manager }\end{array}$ \\
\hline $\begin{array}{l}\text { Element of } \\
\text { time }\end{array}$ & $\begin{array}{l}\text { - prepared to conclude } \\
\text { contracts for a definite } \\
\text { period of time, } \\
\text { - for the term of specific } \\
\text { tasks to be implemented." }\end{array}$ & $\begin{array}{l}\text { - when employing an expert } \\
\text { on a permanent basis } \\
\text { cannot be justified } \\
\text { economically." }\end{array}$ & - "over a finite time span". \\
\hline
\end{tabular}

Adapted from: "Interim management jako forma doskonalenia biznesowego i zawodowego" [Interim management as a form of business and professional improvement] by B. Skowron-Mielnik and M. Bądzio, 2016, Zeszyty Naukowe Politechniki Śląskiej.

With interim management responding to the same needs of the organization, regardless whether it is a relatively young phenomenon (Poland), a well-established one (the UK) or it is perceived from the international perspective (worldwide), it may be intuitively anticipated that based on scientific research some common conclusions will be possible to be drawn about interim management and how it is related to the organization's needs. Indeed, Goss and Bridson (1998) offer a motive-based typology of interim managers in relation to business needs. They juxtapose the characteristics of the supply side (interim manager) and the demand side 
(the client's organization), searching for sources of both the project success and the risk of its failure in aligning the two as soon as at the stage of diagnosing the needs.

Table 3.

Typology of interim management juxtaposed with the organization's needs

\begin{tabular}{|c|c|c|c|c|c|}
\hline \multirow[t]{2}{*}{ Type of IM } & \multicolumn{2}{|c|}{$\begin{array}{l}\text { Supply side - } \\
\text { Characteristics of individual }\end{array}$} & \multirow{5}{*}{ 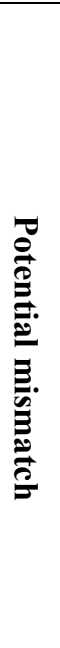 } & \multicolumn{2}{|c|}{$\begin{array}{c}\text { Demand side - } \\
\text { Organizational requirements }\end{array}$} \\
\hline & Motive & Capability & & Need & Role \\
\hline $\begin{array}{c}\text { A. } \\
\text { Simple }\end{array}$ & $\begin{array}{c}\text { Route to } \\
\text { permanent job }\end{array}$ & $\begin{array}{l}\text { Operational and } \\
\text { supervisory } \\
\text { competencies }\end{array}$ & & $\begin{array}{l}\text { A. } \\
\text { Instrumental } \\
\text { resourcing - } \\
\text { stopgap }\end{array}$ & Managerial temp \\
\hline $\begin{array}{c}\text { B. } \\
\text { Formal }\end{array}$ & $\begin{array}{l}\text { Best present } \\
\text { option }\end{array}$ & $\begin{array}{l}\text { High level } \\
\text { functional } \\
\text { specialism }\end{array}$ & & $\begin{array}{l}\text { B. } \\
\text { Functional } \\
\text { resourcing - } \\
\text { stopgap }\end{array}$ & Applied consultant \\
\hline $\begin{array}{c}\text { C. } \\
\text { Sophisticated }\end{array}$ & $\begin{array}{l}\text { Commitment to } \\
\text { IM career }\end{array}$ & $\begin{array}{c}\text { Strategic, } \\
\text { entrepreneurial } \\
\text { competencies and } \\
\text { executive } \\
\text { experience }\end{array}$ & & $\begin{array}{l}\text { C. } \\
\text { Transitional } \\
\text { resourcing- } \\
\text { stopgap }\end{array}$ & $\begin{array}{c}\text { Transformational } \\
\text { leader }\end{array}$ \\
\hline
\end{tabular}

Adapted from: "Understanding interim management" by Goss D. and Bridson J., 1998, Human Resources Management Journal, Vol. 8 No. 4.

After approximately 20 years since the publication of Goss and Bridson's definition presented in Table 3, its comparison with the contemporary definitions summarized in Table 2 shows that the latter focus on interim management of type $\mathrm{C}$. Intuition suggests that for each of the three types marked A, B and C in Table 3, Trust, Knowledge and Power may prove to be the success factors behind IM projects. However, the level of Knowledge required from an interim manager will be the highest in $\mathrm{C}$, where the need to build Trust will be in turn essential to create conditions necessary for the client to grant Power to the interim manager. It therefore seems appropriate to suggest these factors for a research program in the modern understanding of interim management.

Analysing the ways in which interim managers may seek to fill a gap that they as outsiders have in their Knowledge of the organization, its problems and expected results, de Weerd (2015, interviews with three Dutch interim managers) draws a contrast between a consultant and an interim manager with respect to such project attributes as:

- nature of task;

- authority to instruct and to be instructed;

- belonging to the organization measured by time spent on the job.

Conclusions seem to reveal a structure presented in Table 4, with nature of task recognized as a central criterion and thus the pivotal point for the discussion. 
Table 4.

Attributes of an interim manager employed as: a member of leadership personnel, management consultant and interim manager

\begin{tabular}{|l|c|c|c|}
\hline Attributes of employment & $\begin{array}{c}\text { I. } \\
\text { Employed leadership } \\
\text { personnel }\end{array}$ & $\begin{array}{c}\text { II. } \\
\text { Management } \\
\text { consultant }\end{array}$ & $\begin{array}{c}\text { III. } \\
\text { Interim } \\
\text { manager }\end{array}$ \\
\hline A. Nature of task & $\begin{array}{c}\text { Management of the } \\
\text { enterprise }\end{array}$ & Only consultation & Management tasks \\
\hline B. Contract-basis & Labour contract & Service contract & Service contract \\
\hline $\begin{array}{l}\text { C. } \text { Authority to instruct and } \\
\text { to be instructed }\end{array}$ & $\begin{array}{c}\text { Extensive authority. } \\
\text { Subject to instructions } \\
\text { exists. }\end{array}$ & $\begin{array}{c}\text { None } \\
\text { contract }\end{array}$ & $\begin{array}{c}\text { task; subject to limited } \\
\text { instructions. }\end{array}$ \\
\hline $\begin{array}{l}\text { D. Period of belonging to } \\
\text { the enterprise }\end{array}$ & $\begin{array}{c}\text { Permanent labour } \\
\text { Lonthly salary and }\end{array}$ & $\begin{array}{c}\text { Generally daily rate and } \\
\text { expenses }\end{array}$ & $\begin{array}{c}\text { Generally daily rate and } \\
\text { expenses }\end{array}$ \\
\hline E. Compensation & \begin{tabular}{c} 
Mossibly profit sharing \\
\hline
\end{tabular}
\end{tabular}

Adapted from: "The knowledge gap of interim management" by M. Weerd de, 2015, University of Twente, The Faculty of Behavioural, Management of Social Sciences.

Interim managers (column III), in addition to the use of Knowledge as expected of consultants (column II), are also to implement a given solution. In the light of this, the interim managers included in de Weerd's study pointed to three ways in which they acquired knowledge before and after entering the organization:

- Before:

- Reading annual reports and general information about the organization;

- Search in the network of connections of the interim manager for people who may have experience with or within the organization;

- Analysing financial statements for investigation about the current hidden crisis the organization is in.

- After:

- Interviewing employees from all different levels of the organization;

- Attending meetings of the supervisory boards, being only an observer, no communication given;

- Communicating in depth with top management;

- Focusing on informal structure while having conversations with employees and the management.

From the perspective of choosing Trust, Power and Knowledge as factors of IM project effectiveness in the study discussed here, conclusions drawn by de Weerd (2015) point to their important role in meeting the organization's needs:

- The role of Knowledge:

- is not only to be able to apply the knowledge that interim managers already have,

- but also to discover and acquire the knowledge about the organization. 
- Skills to diagnose Trust:

- Interim managers should have special skills to discover trust-based relationships in the organization and determine the level of trust in these relationships;

- Interim management consists in cooperation (connections) and relationships in the organization.

Basing on interviews with interim managers and authorities of three British counties which used IM solutions to implement new labour laws, Gott (2015) finally concludes that interim managers could be perceived as simultaneously playing the three following roles in the project:

- Vanguards of new laws: “(...) permanent managers (were) adopting more efficient and more effective ways of working with interims, and both permanent and interim managers reported working constructively together vast majority of the time" (Gott, 2015, p. 8);

- Villains who break the arrangements and relationships existing in the organization prior to the project: "(...) where interims, in an attempt to make organization more efficient and effective, made staff that were seen as inefficient and ineffective redundant" (Gott, 2015, p. 10);

- Victims of new laws because by implementing a project for a client who represents administration they will necessarily face bureaucratic restrictions that affect permanent employees, in particular “ (...) both interim and permanent managers (...) described central government as being overly prescriptive and bureaucratic, (...), and central policy changing too frequently, goalposts being shifted, (...) and lack of joined up working from central government" (Gott, 2015, p. 11).

In reference to these observations, Gott (2015) indicates that Trust is an important factor of effectiveness in IM projects, also in non-business environment. Moreover, Gott characterizes the role of Trust:

“(...) given their externality interim managers can be more challenging and robust in their behavior, but to be challenging effectively, and for staff to feel comfortable in sharing confidences and frustrations, there needs to be trust first (...) and where interim managers are employed to achieve organizational turnaround they need to build relations based on trust and confidence because relationships between senior managers and staff or members and officers have often been dysfunctional" (Gott, 2015, p. 3). 


\section{Interim management and its development in Poland}

While data on the size of international IM markets are available, in Poland it is only the Interim Managers Association (SIM) of Poland that has attempted to annually verify the number of interim managers since 2013. Their findings are summarized in Table 5.

\section{Table 5.}

The IM market in Poland in 2013-2018

\begin{tabular}{|l|c|c|c|c|c|c|}
\hline \multicolumn{1}{|c|}{ Year } & $\mathbf{2 0 1 3}$ & $\mathbf{2 0 1 4}$ & $\mathbf{2 0 1 5}$ & $\mathbf{2 0 1 6}$ & $\mathbf{2 0 1 7}$ & $\mathbf{2 0 1 8}$ \\
\hline Market size (number of IMs) & 300 & 400 & 600 & 900 & 1,400 & 2,000 \\
\hline Market size (number of projects) & 200 & 260 & 450 & 800 & 1,260 & 1,800 \\
\hline Market size (value of projects in million PLN) & 50 & 65 & 110 & 200 & 300 & 450 \\
\hline Number of the SIM members & - & - & - & - & - & 130 \\
\hline Number of members of the SIM group on Linkedin & - & - & - & - & - & 1,000 \\
\hline Number of IMs registered at www.interim24.pl & - & - & - & - & - & 1,100 \\
\hline
\end{tabular}

Adapted from: Interim Managers Association (SIM) of Poland (2017), Interim Management w Polsce. Raport z badania rynku 2017 [Interim Management in Poland. Market Research Report 2017]; Interim Managers Association (SIM) of Poland (2019), Interim Management $w$ Polsce. Raport z badania rynku 2018 [Interim Management in Poland. Market Research Report 2018].

A variety of measures had to be applied by the SIM to assess the size of Poland's IM market as in their evaluation they could rely only on the data from $20 \%$ of registered projects in which the IM projects were arranged through recruitment agencies.

Based on this source, it can be concluded that interim managers are mainly people who enter this career path having acquired a lot of experience in top management positions, i.e. as members of management boards or supervisory boards. Strategy, management and sales projects are the most frequent areas in which interim managers work (Figure 2).

Areas of Interim Management projects

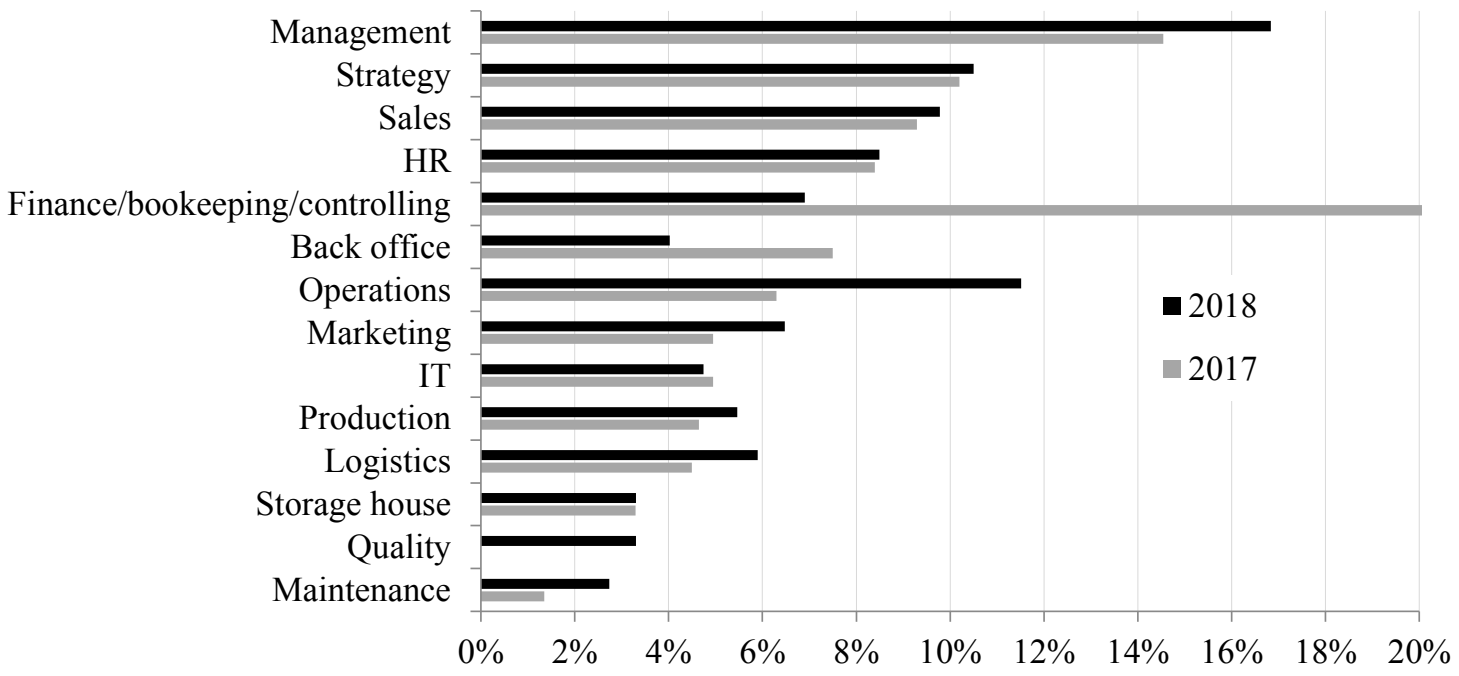

Figure 2. Areas of IM projects in Poland. Adapted from: Interim Managers Association (SIM) of Poland (2017), Interim Management w Polsce. Raport z badania rynku 2017 [Interim Management in Poland. Market Research Report 2017]; Interim Managers Association (SIM) of Poland (2019), Interim Management w Polsce. Raport z badania rynku 2018 [Interim Management in Poland. Market Research Report 2018]. 
The main reasons why management in enterprises decides to reach out for interim managers as their external support are typically related to transformation processes, as shown in Figure 3, with missing competences, changes in the organization and the need for an additional manager recognized as the key reasons for adopting this solution.

\section{Reasons for employing Interim Manager}

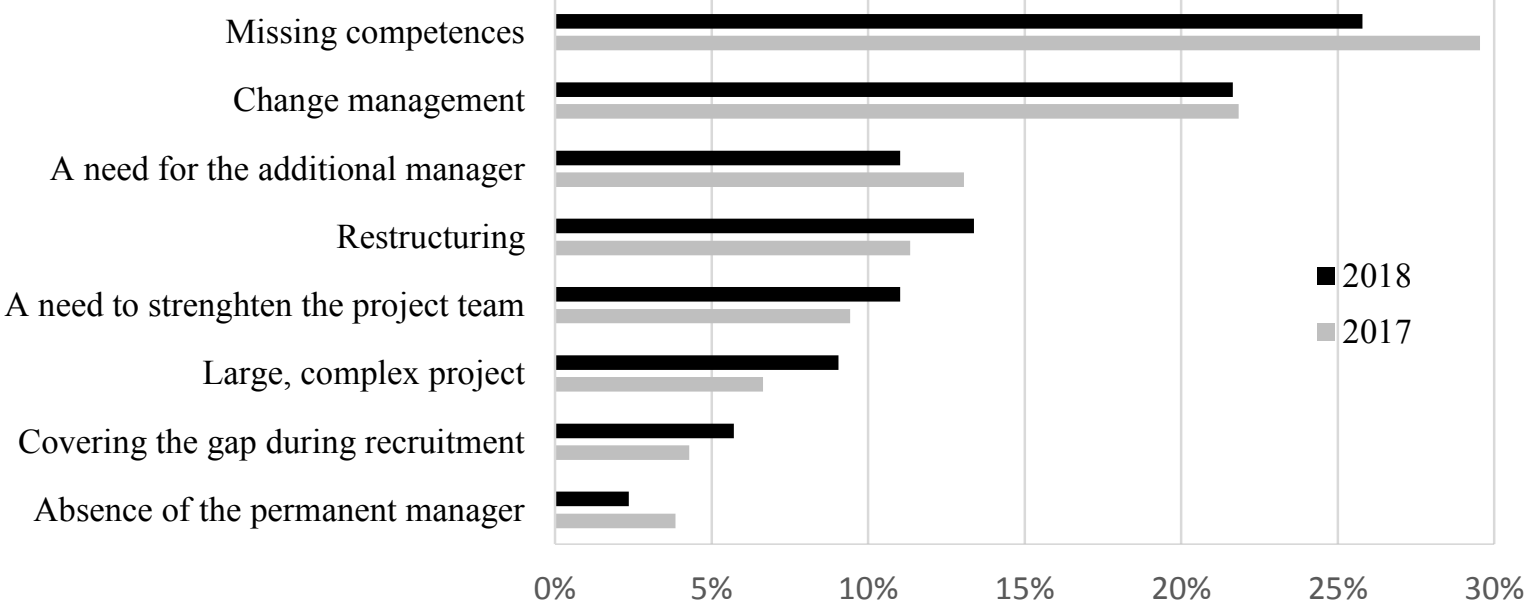

Figure 3. Reasons for employing interim managers in Poland (number of projects). Adapted from: Interim Managers Association (SIM) of Poland (2017), Interim Management w Polsce. Raport z badania rynku 2017 [Interim Management in Poland. Market Research Report 2017]; Interim Managers Association (SIM) of Poland (2019), Interim Management $w$ Polsce. Raport z badania rynku 2018 [Interim Management in Poland. Market Research Report 2018].

According to the data in Figure 4, the vast majority of interim management projects last six months or less, with those extending over the period of 6-12 months being more than twice as rare.

Length of interim management projects

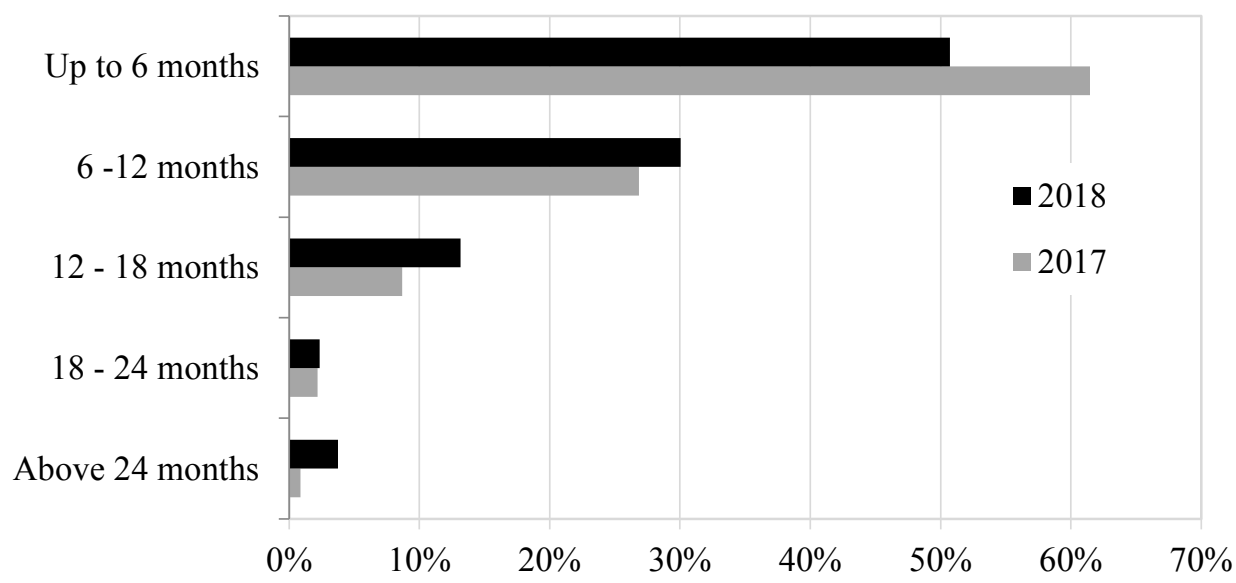

Figure 4. The average length of IM projects in Poland. Adapted from: Interim Managers Association (SIM) of Poland (2017), Interim Management $w$ Polsce. Raport z badania rynku 2017 [Interim Management in Poland. Market Research Report 2017]; Interim Managers Association (SIM) of Poland (2019), Interim Management w Polsce. Raport z badania rynku 2018 [Interim Management in Poland. Market Research Report 2018]. 
Interim management projects are not covered by intermediary agencies in Poland on a large scale, with only $18 \%$ of such projects recorded for this type of activity in 2017 . As Figure 5 reveals, the remaining projects are obtained by interim managers themselves independently, either through direct search (advertisement, direct acquisition) or indirectly (networking, former client).

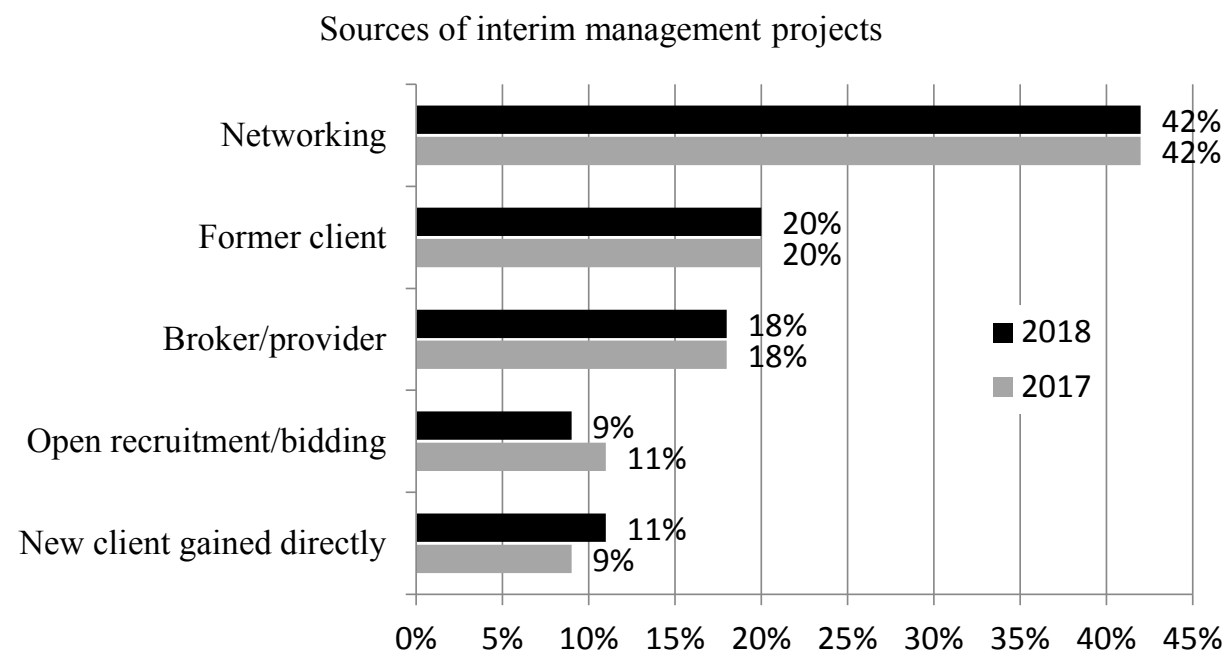

Figure 5. Sources of projects for interim managers in Poland. Adapted from: Interim Managers Association (SIM) of Poland (2017), Interim Management w Polsce. Raport z badania rynku 2017 [Interim Management in Poland. Market Research Report 2017]; Interim Managers Association (SIM) of Poland (2019), Interim Management w Polsce. Raport z badania rynku 2018 [Interim Management in Poland. Market Research Report 2018].

In contrast to classical management, as implemented by permanent managers employed full time and well-established in the company (typically with years of employment history in it), interim - and by definition temporary - management is perceived differently by people responsible for decision-making in the organization (Table 6).

Table 6.

Reasons for clients opting for and having concerns about employing IMs

\begin{tabular}{|l|l|}
\hline \multicolumn{1}{|c|}{ Motivators } & \multicolumn{1}{c|}{ Barriers } \\
\hline - Experience. Expecting that the IM & - Power to take decisions. The need for additional legal \\
will bring to the company their know- & safeguards to prevent possible damage to the organization. \\
how and solutions that have worked & - Immediate threat to one's position. As outsiders IMs can \\
out well in other companies. & $\begin{array}{l}\text { replace the company's permanent managers who } \\
\text { consequently may be unwilling to cooperate with them, }\end{array}$ \\
- Experience. Also in the context of the & fearing for their own jobs. \\
$\begin{array}{l}\text { IM's broadly understood contacts and } \\
\text { business connections that may be }\end{array}$ & $\begin{array}{l}\text { Lower morale. A lower morale may be observed along with } \\
\text { availed of during the project. }\end{array}$ \\
- The perspective of an outsider. A & resistance from the team. \\
fresh look, motivation for the & appropriate skills and a limited time to get to know the \\
company to change for the better. & company while it is widely believed that if one wants to \\
- Form of remuneration. An element & make favourable changes they need to know the business \\
that motivates IMs to work & inside out. \\
effectively, a solution beneficial for & - Experience. Doubts whether it is possible to find an IM \\
the organization. & whose skills will prove adequate to a particular industry. \\
\hline
\end{tabular}

Adapted from: Interim Managers Association (SIM) of Poland, available at:www.stowarzyszenieim.org. Studies carried out by the SIM in cooperation with TNS 2012. 
This compilation shows crucial factors that may predetermine not only the decision but also the nature and effectiveness of cooperation with IMs. In the absence of research dedicated to this area in Poland, British studies may be used to shed some light on this issue. According to them, in terms of personality type/behavioural preference, based on Myers-Briggs Type Indicator (MBTI) IMs tend to have a strong disposition for featuring a combination of such characteristics as extroverted, visionary, planful and methodical (Figure 5).

In the light of this, a gap may be spotted in research on Polish interim management including the following elements:

- Currently available publications are indeed those of empirical and declarative conclusions on rules of conduct and IM project effectiveness factors as drawn by IMs themselves and from the operational perspective (e.g. Mądra et al., 2014).

- The authors of this article have not been able to find a study on IM project effectiveness factors that would adopt the organizational perspective.

Personality types of British Interim Managers

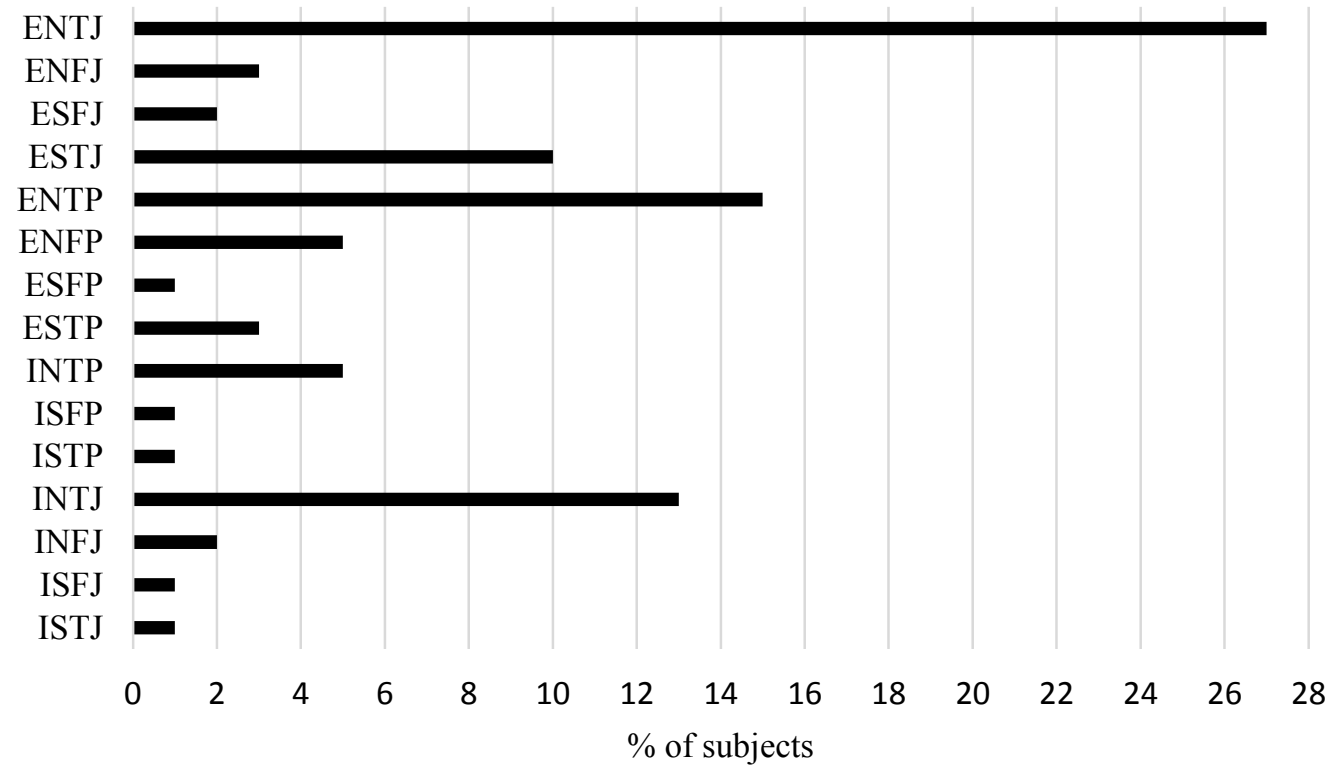

Figure 6. Personality types of British Interim Managers [\%]. Adapted from: Institute of Interim Management, 2014.

In conclusion, a gap exists in research on the state of interim management and its development in Poland as exemplified by rather scarce and randomly scattered online theoretical sources and empirical data. At the same time, the available material, albeit based mainly on limited study populations, seems to indirectly point to the role that the factors of Trust, Knowledge and Power may play to ensure effective satisfaction of the organization's needs through the use of interim management solutions. 


\section{The concept of a research model for IM project effectiveness factors}

Adapting the research program model allows us to show the progress of our work (Figure 7) and thus present Figure 8 (below) at this stage to further unveil the initial concept of our research model (step 8 in Figure 7).

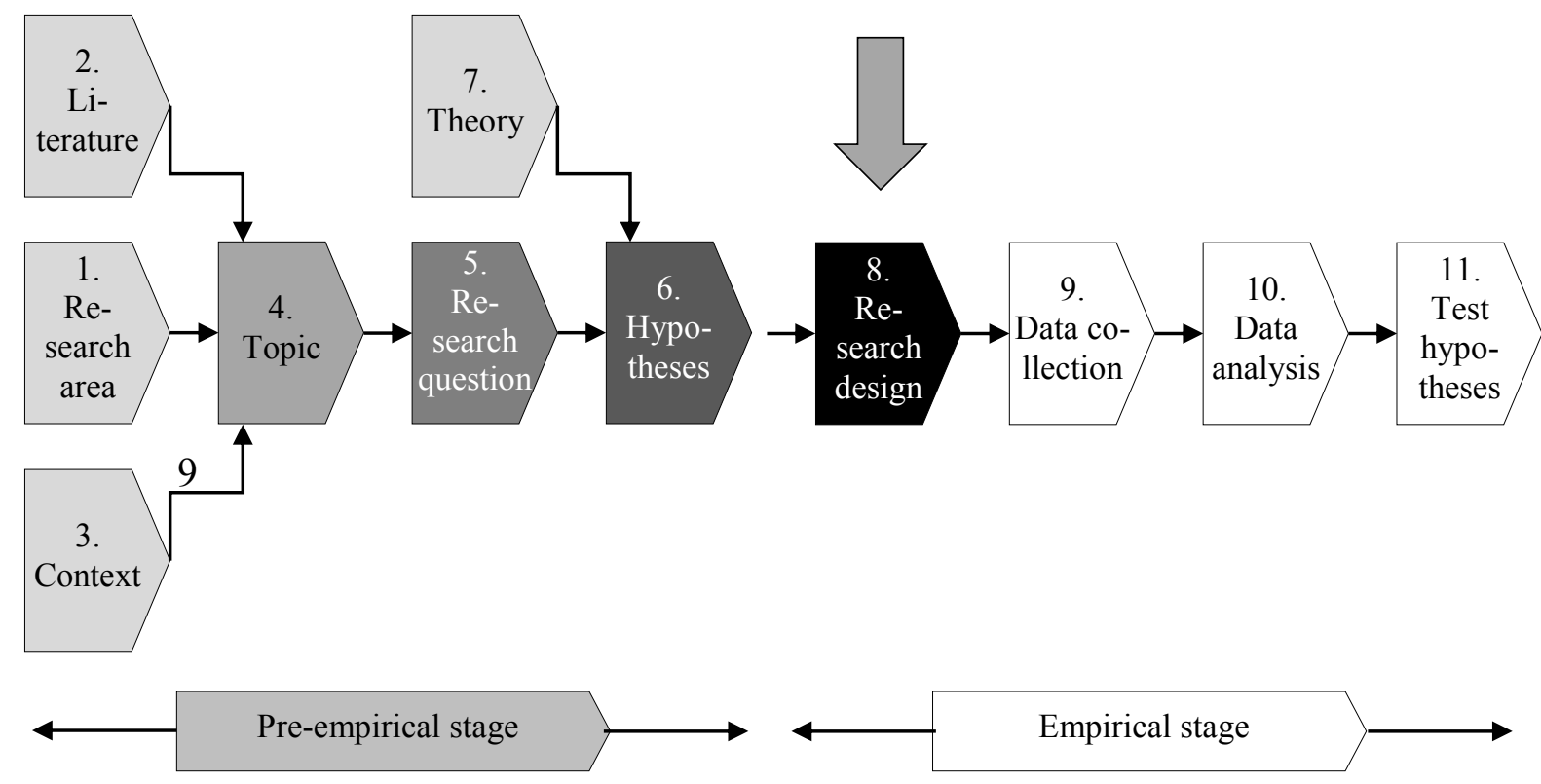

Figure 7. The advancement of works on the research program. Adapted from: "Developing Effective Research Proposals" by K.F. Punch, 2016, London, California, New Delhi, Singapore: Sage Publications.

Based on the studies of available sources, three factors were agreed to have an impact on IM project effectiveness: Trust, Power and Knowledge. Consequently, they were analysed from four perspectives:

- From the perspective of conclusions drawn from the review of subject literature on meeting the organization's needs through the use of IM solutions;

- From the perspective of the identity of interim managers;

- From the perspective of clients - companies that employ interim managers;

- From the perspective of principles governing the IM project market.

\section{Literature review}

The review of the subject literature, albeit based on the scarce publications available, resulted in the proposal to recognize the role of Trust, Knowledge and Power as important in the discussion on the effectiveness of IM projects, both in commercial and political organizations. 


\section{Perspective of the identity of interim managers}

The perspective of interim managers led the authors to pre-admit (i.e. as a result of cyclic iterations of the research process carried out so far in steps 1 through to 8) the proposal suggested by Mądra et al. (2014) as the foundation for the pre-empirical stage illustrated in Figure 7. In particular, inspired by the ideas proposed by Mądra et al. (2014) in terms of factors that have an impact on IM project effectiveness from the organizational perspective, the said three factors (Trust, Power and Knowledge) were found significant enough to be included in the proposed research program (according to step 5 in the model as presented in Figure 7).

\section{Perspective of clients}

Looking from the clients' perspective, the observations presented in Figure 3 (see Section 3 above), collected as part of direct interviews with clients availing of IM services, seem to additionally strengthen the argument for selecting these three factors. The clients' concerns and motivators listed in Figure 3 may accordingly be grouped in relation to Trust, Power and Knowledge:

- Trust

- Doubts whether it is possible to find an IM whose skills will prove adequate to a particular industry;

- Risk of possible damage to the organization;

- As outsiders IMs can replace the company's permanent managers who consequently may be unwilling to cooperate with them, fearing for their own jobs;

- Power - The need for additional legal safeguards to prevent possible damage to the organization;

- Knowledge

- Concerns about IMs having the appropriate skills and a limited time to get to know the company while it is widely believed that if one wants to make favourable changes they need to know the business inside out;

- Expecting that the IM will bring to the company their know-how and solutions that have worked out well in other companies;

- A fresh look, motivation for the company to change for the better.

\section{Perspective of the market}

Looking from the market perspective and based on the data discussed in Section 3, a number of conclusions are proposed and accordingly presented in Table 7.

With these four perspectives of looking at the needs of the organization, interim managers, clients and the market combined, research questions were formulated to seal the said research gap basing on the research model proposed by Punch (2016). Proceeding successively from 
step 1 to step 8 at the pre-empirical stage (Figure 7), the following components of the research program model are suggested (see below).

Table 7.

Market-observations regarding the IM effectiveness factors

\begin{tabular}{|c|c|}
\hline Observations & Effectiveness factor proposal \\
\hline $\begin{array}{l}\text { Main reasons for employing an IM: } \\
\text { - } \quad \text { Provision of the missing competences (trust) } \\
\text { - primary reason for employing an IM; } \\
\text { - Change management (power) - second most } \\
\text { important reason for employing an IM. }\end{array}$ & $\begin{array}{l}\text { Trust - the thought that an outsider is to enter the } \\
\text { company to meet its crucial needs can have an effect } \\
\text { on decisions related to giving them employment and } \\
\text { power. }\end{array}$ \\
\hline $\begin{array}{l}\text { Main areas of IM projects: } \\
\text { - Management, i.e. placing the power in the } \\
\text { hands of an outsider - primary area of IM } \\
\text { projects; } \\
\text { - Strategy, where both the IM's experience } \\
\text { and strategic knowledge may have a } \\
\text { significant impact on the project in terms of } \\
\text { its effectiveness; } \\
\text { Sales, i.e. an area in which knowledge - } \\
\text { expressed as the knowledge of the industry } \\
\text { in which the client's company operates - } \\
\text { may determine the trust placed with the IM. }\end{array}$ & $\begin{array}{l}\text { Power and knowledge - may prove significant if the } \\
\text { most important projects pertain to management, } \\
\text { strategy and sales. }\end{array}$ \\
\hline $\begin{array}{l}\text { Short duration of a typical project - the vast majority } \\
\text { of projects last approximately six months. }\end{array}$ & $\begin{array}{l}\text { Trust - especially affective, may be more difficult to } \\
\text { verify in such a short time, making trust a factor for } \\
\text { the project effectiveness; also, the IM's ability to } \\
\text { build trust quickly must be taken into account. } \\
\text { Power - the said trust is important for the IM to be } \\
\text { able to obtain sufficient power, for example to } \\
\text { manage change. }\end{array}$ \\
\hline $\begin{array}{l}\text { Sources of new projects: } \\
\text { - Networking } \\
\text { - } \quad \text { Former clients }\end{array}$ & $\begin{array}{l}\text { Trust in the interim manager is crucial in projects } \\
\text { entered into as a result of networking. The interim } \\
\text { manager's knowledge of networking itself is also of } \\
\text { great importance. } \\
\text { If a client trusts an interim manager once again on a } \\
\text { different occasion, this may be due to such factors in } \\
\text { the previous project as: trust gained, power granted } \\
\text { and knowledge demonstrated at that time. }\end{array}$ \\
\hline
\end{tabular}

Source: Own study.

\section{Pre-empirical stage}

1. Step 1. Research area: Interim management projects.

2. Step 2. Literature: Mądra et al., 2014, as an inspiration to review literature for Research Theory (Step 7 in Figure 7).

3. Step 3. Context: Polish market of interim management projects (Section 3 above).

4. Step 4. Research topic: Factors of Trust, Power and Knowledge associated with the effectiveness of interim management projects (compilation of observations from three perspectives: IM, client, market). 
5. Step 5. Research questions:

5.1. General research question: What is the relationship between the organizational factors such as Trust, Power and Knowledge proposed by Mądra et al. (2014) and the effectiveness of interim management projects?

5.2. Specific research questions:

5.2.1. Specific research question 1: What is the relationship between the factor of Trust and the effectiveness of interim management projects?

5.2.2. Specific research question 2: What is the relationship between the factor of Power and the effectiveness of interim management projects?

5.2.3. Specific research question 3: What is the relationship between the factor of Knowledge and the effectiveness of interim management projects?

6. Step 6. Research hypotheses: These will be formulated at the empirical stage (Figure 7), after the accuracy of choosing the said three factors is verified against the literature review (steps 2 and 7), see Point 7 below.

7. Step 7. Theory in literature review: A detailed review of theoretical publications related to the occurrence of factors of Trust, Power and Knowledge in the theory of management will be carried out as part of constructing the assumptions at the empirical stage of the research program in the future. In particular, indicators/measuring instruments will be sought which point to the use of the three factors. At the same time, basing on the review of literature at the empirical stage it will be possible to establish the indicators/measuring instruments that will provide for finding correlations between the three factors and the effectiveness of IM projects.

\section{Empirical stage}

8. Step 8. Research design: In this article the proposal of the research model at stage 4: Research design is presented, as symbolically marked with a vertical arrow in the architecture of the research program model in Figure 7.

9. Step 9. Data collection: Based on the review of literature as specified in Point 7 above, research instruments will be developed. The decision on the possible use of research instruments with documented use, as described in the literature, or originally developed research instruments remains to be taken at the empirical stage. 


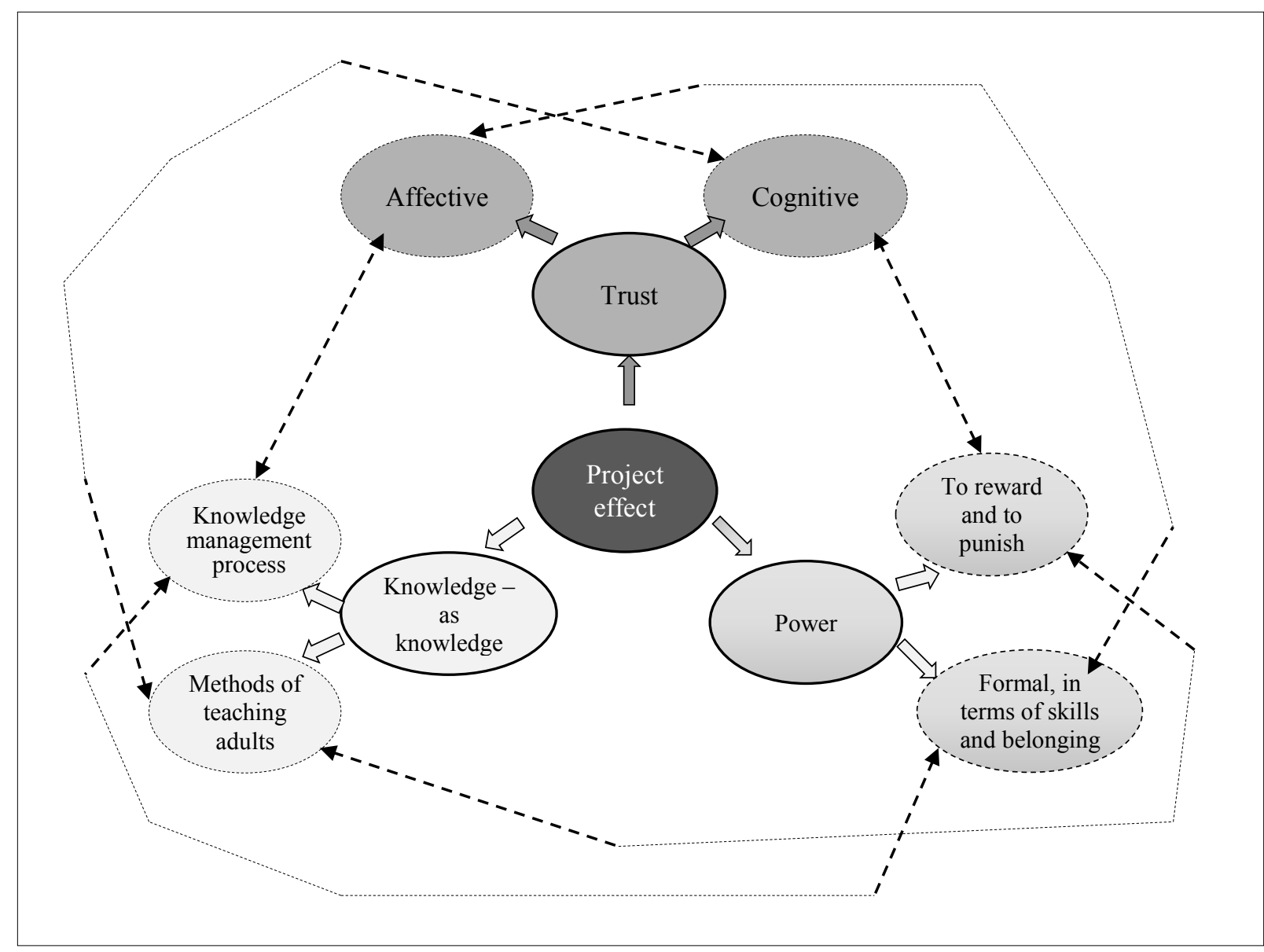

Figure 8. Research model of interdependencies. Source: Own study.

Using the research model presented in Figure 8, theoretical foundations of Knowledge, Power and Trust will be determined. In particular, the three effectiveness factors will be studied for their presence in literature as isolated constructs, constructs studied in pairs or all three together. In the summary, research instruments will be selected which on the one hand meet the theoretical requirements and on the other comply with the comprehensive criteria of their application to studying interim management.

\section{Summary}

From the perspective of European markets, interim management has evolved over the past few decades to eventually focus on projects implemented in a selected number of areas where the most difficult tasks in a company are faced: strategy, sales and business model transformation.

Looking historically from the perspective of Polish market, interim management is a relatively new phenomenon. Nevertheless, Polish interim managers carry out projects benchmarked against an almost identical pattern of areas, while as of yet their methodology and effects have not been sufficiently documented in subject literature. 
With networking and former clients still constituting the main sources of new projects, from this perspective the effects of such projects may be considered positive. The perspective of the project duration allows to determine that projects typically last for six months. Therefore, in research terms it seems interesting to fill the existing research gap and to try to find factors of effectiveness in projects implemented by Polish interim managers, i.e. projects which are difficult, short-term and effective, where former clients tend to return to "their" interim managers and new clients are found directly through networking.

In the article a research question is proposed to seal this gap: Are Trust, Power and Knowledge the factors that may to a large extent determine for a given project to be effective? The pioneering nature of work aimed at filling the existing research gap and answering this research question made the authors opt for an empirical-inductive approach. This is how the research model discussed in Section 4 was developed, which, with the research hypotheses planned in the future, will combine the factors of Trust, Power and Knowledge into a coherent research program laid out in Figure 8.

\section{References}

1. Eurofound (2015). New forms of employment. Luxembourg: Publications Office of the European Union, eurofound.link/ef1461.

2. Eurofound (2018). Overview of new forms of employment - 2018 update. Luxembourg: Publications Office of the European Union, eurofound.link/ef18050.

3. Glaser, B.G., Strauss, A.L. (2009). Odkrywanie teorii ugruntowanej. Strategie badania jakościowego. Kraków: Nomos.

4. Goss, D., and Bridson, J. (1998). Understanding interim management. Human Resources Management Journal, Vol. 8, No 4, pp. 37-50. Retrieved from: https://interimcfo.files. wordpress.com/2015/01/understanding-interim-management.pdf, 8.06.2019.

5. Gott, K. (2009, July $\left.6^{\text {th }}\right)$. Vanguards, villains or victims? What is the identity of the interim manager employed in UK local government in the context of normative New Labour disciurses of efficiency and effectiveness? Paper presented at $6^{\text {th }}$ CMS conference, Warwick, UK. Retrieved from: http://mngt.waikato.ac.nz/ejrot/cmsconference/2009/Stream2/ Vanguards,\%20villains\%20or\%20victims.pdf, 5.06.2019.

6. Institute of Interim Management (2014). IIM Interim management Survey 2014. Retrieved from: https://iim.org.uk/wp-content/uploads/2016/02/IIM-Interim-Management-Survey2014.pdf, 8.07.2018.

7. Interim Managers Association (SIM) of Poland (2012). Studies carried out by the SIM in cooperation with TNS 2012. Available at: www.stowarzyszenieim.org. 
8. Interim Managers Association (SIM) of Poland (2017). Interim Management $w$ Polsce. Raport $z$ badania rynku, http://stowarzyszenieim.org/public/www/media/File/2019/ Raport\%20z\%20badania\%20rynu\%20interim\%20management\%202019.pdf.

9. Interim Managers Association (SIM) of Poland (2019). Interim Management $w$ Polsce. Raport $z$ badania rynku, http://stowarzyszenieim.org/public/www/media/File/ RAPORT\%20Z\%20BADANIA\%20RYNKU\%20INTERIM\%20MANAGEMENT\%2020 17 N.pdf.

10. Mądra, E., Niesiobędzka-Rogatko, K., Sobiecki, G. and Wendt, R. (2014). Metodyka Interim Management. Warsaw: Z.P. OFFDRUK s.c.

11. Punch, K.F. (2016). Developing Effective Research Proposals. London-California-New Delhi-Singapore: Sage Publications.

12. Rytka, E. Personal website. Retrieved from: http://aktyre.pl, 10.6.2019.

13. Skowron-Mielnik, B. and Bądzio, M. (2016). Interim management jako forma doskonalenia biznesowego i zawodowego. Zeszyty Naukowe Politechniki Śląskiej 2016, Seria Organizacja i Zarzadzanie, z. 97, Nr kol. 1964, pp. 449-460. https://stowarzyszenieim.org/ public/www/media/File/2018/35_po_rec_001_Skowron-Mielnik_1.pdf, 1.07.2018.

14. Sobiecki, G. (2018). Koncepcja Interim management w praktyce. In: M.D. Głowacka and H. Mruk, Zarzadzanie sfera zdrowia (pp. 146-162). Poznań: Polskie Towarzystwo Nauk o Zdrowiu.

15. Sobiecki, G. Personal website. Retrieved from: http://www.bmps.pl, 10.6.2019.

16. Weerd de, M. $\left(2015\right.$, July, $\left.2^{\text {nd }}\right)$. The knowledge gap of interim management. Paper presented at $5^{\text {th }}$ IBA Bachelor Conference, Enschede, The Netherlands, University of Twente, The Faculty of Behavioural, Management of Social Sciences. Retrieved from https://essay.utwente.nl/67386/1/de\%20Weerd_BA_Management\%20\&\%20Governance. pdf, 9.06.2019.

17. Wendt, R. Personal website. Retrieved from: http://wendt.pl, 10.6.2019. 